\title{
Social Welfare and Access to Housing Among the Middle and Low-income Earners in Nigeria: A Review of Frameworks for Housing Delivery
}

\author{
Abdullahi, Oladimeji Lawal PhD \\ Department of Public Administration, Faculty of Arts and Social Sciences, Gombe State University
}

\begin{abstract}
Adequate housing is one of the necessities of a qualitative life. It is only next to food and clothing in importance and contributes to the attainment of the physical and moral health of a nation. Decent housing also stimulates the social stability and economic development for the country. Successive Governments have attempted to provide access to qualitative housing for low-income groups without meaningful results. This study, therefore, interrogates the role of social welfare in enhancing access to housing among the middle and low-income earners to ascertain the extent to which the frameworks for housing delivery in Nigeria advance the welfare of the poor. With the aid of Social Democratic theory, the study opines that access to housing can only be democratized for all classes of income groups when the principle of social welfare constitute the foundation of the framework for housing delivery. The study used documentary tools in the generation of its data and analytical approach in its analysis. The study discovered among others; that social welfare orientation plays crucial roles in the creation of universal access to housing in several advanced countries around the world, and the lack of social welfare principle in the frameworks for housing delivery in Nigeria is to a large extent responsible for the ever-widening housing gap in the country. The study recommends that the Federal Government should undertake a review of the frameworks for housing delivery in order to establish the social welfare principle as a cardinal principle in the housing delivery strategies for the middle and low-income earners in the country.
\end{abstract}

Keywords: Social welfare; Access to housing; Middle and Low-income Earners; Housing Delivery Framework; Housing Delivery.

DOI: $10.7176 /$ PPAR/11-1-08

Publication date: February $28^{\text {th }} 2021$

\section{Introduction}

Housing can be defined as a physical structure built for habitation. It is an indispensable component of any meaningful existence of human being. Housing is only next to food and clothing in terms of priority. Adequate housing contributes to the attainment of the physical and moral health of a nation and stimulates the social stability, the work efficiency and the development of the individuals" (Olayiwola et al. 2005, p.2). Unlike other commodities housing by its nature is usually exceptionally expensive both in terms of purchase and renting. In other words, due to certain unique features of housing, housing markets are unable to operate smoothly like other markets of other commodities. This peculiarity of the housing market has, however, not made housing product less useful among different categories of income groups in the society. Naturally, the high-income groups in a capitalist society like Nigeria have unlimited access to decent housing. The disadvantaged and indeed, burden groups are those whose income can be categorized as middle and low in society. For the latter group, Government intervention in housing delivery is essential, especially in order to guarantee their welfare. The right to adequate housing that is safe, secure, healthy, available and inexpensive is enshrined in the Habitat Agenda, the global call on human settlement and shelter (UN-Habitat, 2001).

Furthermore, available records show that successive governments in Nigeria have attempted to address the difficulty of accessing decent housing among the middle and low-income earners, albeit unsuccessfully. Aduwo, Edewor \& Ibem (2016, p.354) observes that "between 1975 and 2010, a number of social housing programmes involving direct construction of housing by the government were initiated by both the Federal 
Military and Civilian Governments in Nigeria." The table below captures, in summary, the various low-cost housing Schemes by the Federal Government, their targets, the number of housing units delivered, and the percentage of achievement with the set target.

Table 1: Low-cost Housing Schemes by the Federal Government of Nigeria (1962-2010)

\begin{tabular}{|l|c|c|c|}
\hline Period & $\begin{array}{l}\text { Proposed number of housing } \\
\text { units }\end{array}$ & $\begin{array}{l}\text { Number of housing } \\
\text { units Produced }\end{array}$ & $\begin{array}{l}\text { Percentage of } \\
\text { Achievement (\%) }\end{array}$ \\
\hline $1962-1968$ & 61,000 & 500 & 0.81 \\
\hline $1971-1974$ & 59,000 & 7,080 & 12.0 \\
\hline $1975-1980$ & 202,000 & 30,000 & 14.85 \\
\hline $1981-1985$ & 180,000 & 47,234 & 26.24 \\
\hline $1986-1999$ & 121,000 & 5,500 & 4.55 \\
\hline $2000-2003$ & 20,000 & - & 4.67 \\
\hline $2004-2006$ & 18,000 & 840 & 43.23 \\
\hline $2006-2010$ & 10,271 & 4,440 & 14.63 \\
\hline Total & 653,271 & 95,594 & \\
\hline
\end{tabular}

Source: Adapted from Aduwo, Edewor \& Ibem (2016)

The table above shows that there is a far cry between the targets for each of the housing schemes and the units of houses delivered over the period. This gap also indicates that the Government institution(s) saddled with the responsibilities of delivering the housing targets lack the capacity. Moreover, the table also shows that housing projects meant for the benefit of the low-income groups were not delivered, thereby exacerbating the problem of lack of access to housing. This paper, therefore, interrogates the role of social welfare in enhancing access to housing among the middle and low-income earners in Nigeria with a specific focus on the existing frameworks for housing delivery.

\section{Statement of the Problem}

This paper examines the role of social welfare in enhancing access to decent housing among the middle and low-income earners in Nigeria with particular focus on frameworks designed for housing delivery. Housing is one of the basic needs of man both for a healthy and qualitative living. Social welfare dictates that essential goods such as housing should be covered by government intervention in order to reduce the burden of the citizenry in meeting with its cost on the one hand, and improve the living conditions of the people on the other.

However, the reality in terms of access of the middle and low-income groups to decent housing is a far cry from the ideal as dictated by social welfare. There is an acute shortage of access to decent housing among the middle and low-income earners in Nigeria. The urban housing deficit in Nigeria estimated at between 0.85 million and 1.03 million in 1988 degenerated to 15 million as of 2008 (Oladimeji, 2015, p. 5-6). Oyewole (2018) contends that the housing shortage in the country if statistically conducted is over 22 million and counting. Paradoxically, the worsening housing deficit does not mean that no new houses are being delivered. Rather, it is an indication of 'scarcity amid plenty' as new houses are being added to housing stocks in the country through Government (Federal and State) agencies, private developers, and individual building arrangements. The crux of the urban housing challenge is that of affordability. Lawal and Adekunle (2018, p.3) argue that affordable housing is a decent housing whose cost of either purchase or renting does not exceed $30 \%$ of gross household income. The middle and low-income groups are particularly disadvantaged in securing access to decent housing as a result of the unaffordability of the cost of housing in the country. Olayiwola et al. shared this position as follows: 
Housing difficulties is severe among the low-income groups where problems have been complicated by rapid growth, inflated real estate values, speculative activity, influx of poor immigrants and lack of planning $(2005, p .2)$

Similarly, Makinde (2014) argue that home prices and rents have grown ahead of general inflation, while the composition of homes for sale and rent on the market has been inexorably shifting towards expensive homes. The overall effect of this situation is that the cost of adequate housing is currently beyond the reach of most (middle and low-income earners) Nigerians. "The challenge, therefore, is to provide not only houses but also to make the houses affordable to the urban lower income group" (Onyekachi, 2015, p.3). An attempt to juxtapose the difficulty in securing housing among the low-income earners with the failure of the various low-cost housing schemes to attain their targets inextricably bring to mind certain pertinent questions such as what is responsible for the persistent failure of Government to realize the goals of "housing for all"? Are there constraints to the institutions saddled with the responsibilities of delivering affordable housing in the country?

This study is particularly interested in the social welfare perspective on housing delivery. Hence, it seeks answers to the following questions:

i. How crucial is the principle of social welfare to enhancing access to decent housing among the middle and low-income earners?

ii. To what extent did the frameworks for housing delivery programmes in Nigeria facilitate access to decent housing for the middle and low-income earners?; and

iii. What loopholes are inherent in the housing delivery frameworks to the disadvantage of the middle and low-income earners in Nigeria?

\section{Methodology}

The paper used a descriptive and analytical method. This approach relies on existing literature and official records on the subject matter. Official records were obtained from institutions like the UN-Habitat, the Federal Ministry of Works and Housing, and Government Gazettes. In analyzing the obtained information, content analysis approach was adopted by a way of focusing attention on the relevant sections of literature to frameworks for housing provision in the country.

\section{Theoretical Framework}

Several theoretical constructs abound with which analysis of the issues within the housing sector in Nigeria can be undertaken. However, this paper finds the Social Democratic theory propounded by Broadbent (1977) very instructive. While the theory believes in the perfect market ideas of fairness, balance, and diversity; it imposes on the State, the task of ensuring that no single group ends up in an excessively privileged position. The major contention of this theory is that:

\section{The Government should intervene in the housing sector to ensure decent basic standards of housing for lower-income families. Social democratic equity requires assistance to house the poor, particularly households too poor to afford decent accommodation without paying an excessive proportion of their income for it (Heady, 1978, p.21).}

The above points to the fact that the Government should provide a good quality environment to the extent that housing resources are so re-distributed such that the low-income bracket could be favoured. Broadbent (1977, p.205) added that sincerity of those people with interest in the outcome of a political decision would become politically active. Since the weak polity is responsive to external pressures, the outcome will faithfully reflect the balance of interest in a community. The preceding argument as it relates to housing policy by the Government reflects what Kirk (1980) calls "implicit egalitarianism". If the distribution of housing resources is to be democratized, it follows that three groups: low, middle and high-income groups could have some access to the resources on the average. This study, therefore, argues that the frameworks for housing delivery are fundamentally defective in the sense that they did not factor welfare of the poor in articulating the strategies for the provision of affordable housing for the middle and low-income earners as a welfare programme. The housing gap in the country can only get worse unless there is a meaningful and welfare-oriented review of the existing housing delivery frameworks in the country. 


\title{
5. Conceptual Issues
}

\subsection{Social welfare}

The subject matter of social welfare is a wide and diverse one. As a result of its diverse nature, the subject continued to attract varied definitions and perspectives. Punekar (1959) observes that some confusion regarding the meaning of concepts such as social welfare, social service, social work, and welfare work arise due to the dynamic character of social welfare, its recent emergence and importance, and the existence of innumerable social problems, particularly in an underdeveloped country. Despite the confusion about the meaning of the term, scholars have defined the concept. Klein (1968) defines social welfare as "the administration of certain services to individuals and families who find it difficult or impossible to maintain themselves and their dependents in material solvency and health by their efforts".

The key issues in the discussion of social welfare are social and welfare. Welfare provision, according to Spicker (1988) "serves mainly the physical and material interests of recipients. Interests are linked both with people's needs and which are socially defined and with what people want." This definition means that while welfare provisions aim at meeting recipients' interests, such interests are usually defined in a social context. Another dimension of social in welfare provision is that "when the services are articulated for group and community interests for the sole purpose of improving the living conditions of the citizenry" (Umar \& Tafida, 2015). They argue that welfare is:

\begin{abstract}
An institution comprising policies and law expressed by organized activities of voluntary (private) and government (public) agencies by which a defined minimum of social services, money and other consumption rights are distributed to individuals, families and groups by certain criteria other than those of the market place or those prevailing in the family system for the purpose of preventing, alleviations or contributing to solution of recognized social problems, so as to improve the wellbeing of the individual, group and communities directly (Umar \& Tafida, 2015, p.60)
\end{abstract}

Nino-Zarazua $(2019$, p.3) observe that over the past two decades, social assistance emerged as a new paradigm in the fight against poverty and vulnerability in the Global south. He maintains that social assistance includes tax-financed and donor-funded social welfare programme that are designed to provide income and/or inkind support to people living in poverty or in situations of vulnerability. Examples of social assistance include Conditional Cash Transfer (CCTs) programme such as Brazil's Bolsa Familia and Mexico's ProgresaOportunidadas-Prospera; social pensions such as South Africa's Old-Age Pension and India's Indira Ghandi National Old Age Pension Scheme etc.

\subsection{Housing/Access to Housing}

Housing refers to any structure intended or used as a habitation or shelter for animals of any kind, especially a building or edifice for the habitation of man; a dwelling place; a mansion. Kabir and Bustani (2009) argue that housing is defined as buildings or other shelters in which people live, a dwelling. Hence, housing is any structure used for habitation for animals of any kind, especially human being. Mandelker and Montgomery (1973) offer a more comprehensive definition and significance of housing. According to them, housing is much more than physical structures; housing is/has become a subject of positively charged emotional content: a matter of intense feeling. It is the symbol of status, of achievement, of social acceptance. It seems to control, in no small measure, how the individual, the family perceives him/itself and is perceived by others.

Housing has been ranked universally as the second most essential human need after food. Mitchell and Bevan (1992, p.3) opine that "the purpose of shelter includes protection from the extremes of climate, heat, humidity, rainfall, snow, dust and wind. They also include personal or group security". Furthermore, because humans are supremely social creatures, shelter is usually a focus for social living, for the raising of the very young, for the care of the very old, for the preparation and storage of food, rest and sleep. In the words of Anugwom (2001, p.6) there is also no gainsaying the fact that a well-sheltered or accommodated worker, free from the perpetual worries of shelter, will invariably make a more productive and satisfied worker than his colleague who suffers the reverse situation. Thus, housing is an essential item in the daily and meaningful living of human being. Access to housing, on the other hand, is concerned about how easy or otherwise it is for an individual or a family to acquire a house for him/ itself. The acquisition may be in the form of purchases or renting, depending on the choice of the individual. 
Access to housing can also be seen as housing affordability. It has been argued that for housing to be affordable for the low-income earners, it must be tailored to total income level. "Inexpensive housing is used to define dwelling units whose total housing budgets are considered reasonable to a group of people in a definite salary scale" (Iheme, Effiong \& Ekung; 2015, p.89). Along this direction, Lawal \& Adekunle (2018) contends that an affordable housing is a dwelling whose cost of either purchase or renting does not exceed $30 \%$ of the gross household income. Affordability is therefore fundamental to any societal housing scheme.

\title{
6. Social Welfare in Housing Delivery
}

The preceding sections in this paper have not only shown the significance of qualitative housing to human life; it has also revealed that housing by its nature is a costly commodity and if left to the vagaries of market forces, those whose level of income is low stand no chance of having access to qualitative accommodation. Adediji (2006) stated that a household survey in Nigeria indicates that accommodation takes a generous portion of s salary earner and has remained a standard for judging any regime's performance in the socio-economic and political spheres of a country. The expensive nature of housing brings to the fore the question of the place of social welfare in housing delivery. In other words, how does social welfare influence housing delivery? There is consensus among scholars and housing practitioners that housing is one of the most expensive necessities of life. As such, without carefully designed strategies, affordable housing would remain out of reach of the low-income groups. Zedlewski (2002, p.2) opines that "housing assistance can make a significant difference in the economic wellbeing of low-income families. Similarly, Fahey and Worris $(2011$, p.44) argue that helping the less well-off to purchase their own homes is a practice in many western states and is at the centre of social housing policy in a small number."

Many scholars have suggested that such policy is justified by the social insurance effect of home ownership-it frontloads saving and investment in the housing onto the active stages of the life cycle to the benefit of the later stages when mortgages are paid off, and housing costs become small. Onyekachi (2015) alluded to the positive role of government involvement in housing employment creation and income generation segment of any country. In his word:

\begin{abstract}
A dormant housing sector translates to low employment of opportunities. The involvement of public and private sectors in affordable housing provision strengthens the capacity of housing production and also generates employment opportunities and stimulates activities in all other sectors of the economy (Onyekachi, 2015, p.442.)
\end{abstract}

To this end, varieties of housing assistance and support are obtainable across countries. Whereas full government involvement in housing construction exists in countries such as Botswana, Malaysia, among others government limited participation are found in other countries such as the United States of America, the United Kingdom. "With these approaches, many countries have effectively created easy access to decent and affordable housing among the middle and low-income earners (Oladimeji, 2015, p.190). Nino-Zarazua (2019, p.3) opine that " the rise of social assistance reflects important shifts in anti-poverty policy design, moving away from food aid and fuel and commodity subsidies towards the implementation of regular and predictable forms of targeted support". He pontificates that in a sub-Saharan Africa, for instance just about 5 percent of population at the first quintile of the income distribution receives social insurance benefits, and this percentage remains low in the middle-East and North Africa (5 percent), Latin America (8.5 percent), South Asia (20 percent), East Asia and Pacific (21 percent) and particularly so among low-income countries (1.6 percent).

The U.S Department of Housing and Urban Development (2006) in its report of the study of the effect of housing vouchers on welfare families revealed that on several indicators of material well-being, favourable impacts of the vouchers were statistically significant for virtually all types of households in the study. The specific indicators of material well-being covered by the report are:

i. A substantial reduction in homelessness;

ii. An increase in independent housing and a corresponding reduction in doubling-up;

iii. An increase in the average number of rooms for household members and a corresponding reduction in crowding; and

iv. Increased household expenditures on food, which raised average family consumption but did not significantly reduce food insecurity (U.S DHUD; 2006 p.18). 


\section{Housing Delivery Frameworks and the Challenges of Access to Housing among the Middle and Low-income Groups in Nigeria}

Frameworks for housing delivery are structures and institutions designed to meet specific housing goals and objectives. The initial framework for housing delivery in Nigeria is the Ministry charged with the mandate of coordinating the formulation and implementation of housing policies and programmes. Such Ministries are obtainable at both the Federal and State levels. At the Federal level, there is the Ministry of Works and Housing. The Ministry has the mandate to formulate and implement the policies, programmes and projects of the Federal Government of Nigeria (FGN) concerning road transport, highways construction and rehabilitation, highways planning and design; monitoring and maintenance of federal roads and bridges nationwide; provision of infrastructure as well as survey and mapping of the nation's internal and international boundaries (works); and Habitat and affordable housing for Nigerians (Housing) (works and housing.gov.ng).

The Ministries saddled with the responsibility for housing at State level come in varying forms such as nomenclature, mandates and pattern of control. Furthermore, the Federal Housing Authority (FHA) established in 1973 under Decree No.40 is another institutional framework for housing delivery in the country. The FHA established initially to play a dominant role in the implementation of the National housing programme as outlined in the $3^{\text {rd }}$ National Development plan became partially commercialized under Decree 21999 (Oladimeji, 2015, p.121).

Other structures created to facilitate housing delivery are the National Housing Trust Fund (NHTF) established by Decree 31992 and the Federal Mortgage Bank of Nigeria (FMBN) created in 1977. Jolaoso Musa and Oriola (2012, p.430) contends that "the NHTF is a dedicated fund for housing finance established by the Federal Government of Nigeria as one of the key strategies towards the realization of the goals of the National housing policies of 1991, 2001 and 2006". Although there has been significant progress in the design and implementation of public housing policies, many constraints still in effect hinder progress in housing development in Nigeria, particularly the lower-income earners and other vulnerable groups (Onyekachi, 2015, p.444).

Festus and Amos $(2015$, p.55) observed that "at the National level, housing is characterized by abandoned projects, non-implementation of housing policies and neglect of the poor. Mtafu et al. (2011) pointed out that low-income and affordability are significant challenges. In their assessment of the failure of previous social housing schemes in Nigeria, Aduwo, Edewor \& Ibem (2016, p.354) contend that Government-sponsored mass housing schemes are supposed to be based on a three-tier institutional framework involving Federal, State and Local Government as outlined in the National Housing Policy in 1991 and 2012. They insist that while the Federal Housing Authority, Federal Ministry of Land and Housing and the various state Housing corporations have been actively involved in the previous schemes, the third tier of Government the LGAs and community-based organizations such as housing cooperative societies that are supposed to represent the interest of the grassroots people have not been actively involved in such schemes. Ibem, Anosike and Azuh (2011, p.435) argue that consistency and continuity in housing policies and programmes was an essential ingredient (and was lacking) of sustainable public housing delivery system as it engenders proper evaluation and monitoring of the part housing policies, programmes and strategies.

This study, in its review of housing frameworks in the country, alludes to the fact that structures and institutions necessary for housing delivery exist. The structures include a Ministry for formulation and overseeing effective policy (housing) implementation, and an agency with a mandate for direct housing construction (FHA). The Government also created a framework to ease the difficulties in raising funding, especially for the middle and lowincome earners, the NHTF was established, and a Mortgage Bank was set-up to administer the fund. It is, however, instructive to note that one major lacuna and which is mainly responsible for the intractable problem of lack of access to housing among the middle and low-income class is the absence of social welfare principles in the frameworks for housing delivery. Put differently; it is not enough that the Nigerian Government has a multitude of institutions charged with the responsibility for housing delivery one way or the other. Such agencies must in their enabling laws and regulations have a priority for delivery of houses to economically disadvantaged people; otherwise, they run the risk of developing houses only for the rich. The non-capturing of social welfare principles in the existing framework explains the lack of any outstanding support for the middle and low-income earners in the process of housing acquisition.

\section{Conclusion and Recommendations}

Housing is one of the necessities of life without access to which an individual would not live a meaningful life. Access to housing in Nigeria has remained an intractable challenge as the current shortage in housing supply is more than 22 million units. This study contends that the continuous rise in the number of Nigerians without access to housing despite several policy decisions of successive Governments is a result of the neglect of the social welfare 
in the frameworks designed for housing delivery, especially at the Federal Government level. Thus, housing policies and programmes of the Government either succeeded in adding to expensive housing stocks in the country, or the houses delivered by Government agencies remained unaffordable for the low-income earners. Available records show that countries where access to decent housing are widely distributed have concrete mechanisms with which the housing needs of those that are not economically buoyant are protected. In Nigeria, Federal and States Governments must pay serious attention to housing delivery to the middle and low-income groups both as a welfare subject, and a strategy towards stimulating a productive economy.

The loopholes inherent in housing delivery frameworks to the disadvantage of the low-income groups are multidimensional. First, the existing frameworks for housing delivery do not make provision for modalities for government support in providing housing for the poor in the country the consequence of which is that decent housing remains unaffordable for the masses. Second, the mandate given to the Federal Ministry of Works and Housing, as presently structured, only made a passing reference to the provision of affordable housing for Nigerians. The Ministry does not seem to have any clearly defined guidelines about how affordable housing would be delivered to the middle and low-income earners.

Third, the commercialization of the FHA forecloses the possibility of the agency working towards delivering lowincome houses for the low-income groups. The FHA has, therefore focus on providing high-income yielding houses. Forth, the National Housing Trust Fund and the Federal Mortgage Bank of Nigeria (FMBN) both of which were created with the aim of raising fund for housing delivery have access to only limited finance in a year. The limited access to funding by the FMBN is a consequence of the lack of financial support from the Government with which large-scale funding could be pooled for housing agencies to develop low-cost houses. As for the majority of lowincome earners who are either unemployed or are not operating in the formal sector, there exists presently no arrangement to support them in securing access to decent housing.

The implication of these inadequacies is that lack of access to housing among the middle and low-income earners is likely to get worse as Government increasingly sees no priority in supporting those with low-income to overcome their difficulty in securing decent housing. However, the trend can only be reversed if the Government considers and take the following recommendations:

1. There is a need for the Federal Government of Nigeria to review the existing housing delivery frameworks with a view to factoring social welfare principle as a basis for government intervention in housing delivery for the middle and low-income earners.

2. Nigeria Government should appreciate the crucial role of the housing sector both for the wellbeing of the people and in the attainment of economic development. In this wise, due attention should be paid to the housing sector by doing away with the continuous movement of the Ministry of housing. Again, a clear framework to guide the delivery of affordable housing should be developed and implemented by the Ministry.

3. The commercialization of the FHA should be revisited in order to empower it to focus on the provision of affordable housing. Presently, several private housing construction bodies abound all of whom are delivering high-income yielding houses for the benefit of the high-income groups. The FHA, therefore should be made to focus on delivering affordable houses throughout the States of the Federation.

4. There is a need for the Federal Government to design a mechanism to boost the level of funding that will be available to the FMBN. This will increase the number of applicants that could be assisted with housing finance at a given point in time.

5. Guidelines to be provided in delivering housing for low-income groups should also cover the unemployed in society. Such support may be in the form of rent support or subsidy.

\section{References}

Adediji, Y.M.D (2006). Affordable and Functional Housing in a Developing Economy: A Case study of Nigeria, Journal of Land Use and Development Studies, Vol.2 (1) PP 113-120

Aduwo, E.B; Edewor, P.A \& Ibem, E.O (2016). Urbanization and Housing for Low-Income Earners in Nigeria: A Review of Features, Challenges and Prospects. Mechterranean Journal of Social Sciences. Vol.7 No. 351 347-357.

Anugwom, E.E. (2001). Privatization of Workers Housing Provision: the National Housing Fund (NHF) Scheme in Nigeria. African Training and Research Centre in Administration for Development No 571-9. 
Broadbent, T.A (1977). Planning and Profit in Urban Economy; USA:Methuen.

Fahey, T. \& Norris M. (2011). Housing in the Welfare State: Rethinkung the Conceptual Foundations of Comparative Housing Policy Analysis. International Journal of Housing Policy, Vol. 11, No.4 439-452.

Festus, I.A \& Amos, I.O (2015). Housing Policy in Nigeria: An Overview. American International Journal of Contemporary Research. VO1.5, No.2 53-59.

Heady, B. (1978). Housing Policy in the Development Economy; London: Crown Helm

Ibem, E.O; Anosike, M.N \& Azuh, D.E (2011). Challenges in Public housing Provision in the Post-independence era in Nigeria, International Journal of Human Sciences. Vol.8 Issue 2, 421-443

Iheme, J.O; Effiong, J.B; \& Ekung, S.B (2015). The Effect of Government Policy on Housing Delivery in Nigeria: A Case study of Port Harcourt Low Income Housing Programme, International Letters of Social and Humanistic Sciences Vol. 61 PP 87-98

Jolaoso, B.A; Musa N.A; \& Oriola, O.A (2012). National Housing Trust Fund and Low-Income Housing Delivery in Nigeria: A Discourse. Journal of Emerging Trends in Economics and Managemet Sciences (JETEMS) 3(5) 429-438.

Kebir, B. \& Bustani S.A (2009). A Review of Housing Delivery Efforts in Nigeria. Retrieved from http://www.glo.ac.uk/media 129767 en.pdf Isa Internation Conference.

Kirk, G. (1980), Urban Planning in Capitalist Society; London; Croom Helm

Lawal A.O \& Adekunle I.A (2018). Access to Land and the Delivery of Affordable Housing in Nigeria: An Assessment of the Federal Housing Authority (FHA) in Abuja, 1991-2013 Sageopen. https://doi.org/10.1177/2/5824401877728/

Makinde, O.O. (2014). Housing Delivery System, Need and Demand Environ Dev. Sustain Vol.16 49-69, https://doi.org/10.1007/s10668-013-9473-9

Mandelker, D.R \& Montgomery, R. (1973). Housing in America: Problems and Perspectives. Indianapolis, The Bobs-Merrit Company Inc.

Mitchell, M. \& Bevan, A. (1992). Culture, Cash, and Housing Communication Tradition in Low-Income Building; London: Intermediate Technology Publications.

Mtafu, A.Z; Siku, N. \& Diana M. (2011). Understanding Pro-Poor Housing Finance in Malawi. London. International Institute of Environmental and Development.

Muhammed, I.A. (2009). Social Welfare Administration: AnIntroductory Text. Gwagwalada: Chatered Graphic Press.

Nino-Zarazua, M. (2019). Welfare and Redistributive effects of Social Assistance in the Global South, Population and Development Review 45(S1) PP 3-22.

Oladimeji, L.A (2015). An Assessment of the Implementation of Housing Policy in Nigeria: A Study of Federal Housing Authority (FHA), Abuja 1991-2013. Unpublished PhD Thesis University of Abuja.

Olayiwola, L.M; Adeleye, O. \& Ogunshakin, L. (2005). Public Housing in Nigeria: Problems and Challenges, World Congress on Housing, Transforming Housing Environments through the design.

Onyekachi, A.F (2005). Housing the Nigerian Urban Lower Income Group: A Panacea for Industrial Growth. International Journal of Innovation and Scientific Research, Vol. 19 No2, 441-447.

Oyewole, E.A (2018, September 14). Nigeria has over $22 \mathrm{~m}$ housing deficit. Retrieved from https://www.sunnewsonline.com/nigeria-has-over-22m-housing-deficit-oyewole/ on 18/4/2020 at 10:55am

Spicker, P. (1988). Principles of Social Welfare: An Introduction to Thinking about the Welfare State, USA: Routledge.

Umar, H.S \& Tafida, A.D (2015). Democracy and Social Welfare Services in Nigeria A. Perspective of the Forth Republic, Public Policy and Administration Research Vol.5. No 2

United Nationas Centre for Human Settlements (Habitat) (2001). Cities in A Globalizing World: Global Report on Human Settlements. UK: Earthscan publications Ltd.

U.S Department of Housing and Urban Development (2006). Effects of Housing Vouchers on Welfare Families; available at https://www.huduser.gov/Publications/pdf/hsgvouchers_1_2011.pdf accessed on 22/10/2020

Works and Housing.gov.ng

Zedlewski, S.R (2002). The Importance of Housing Benefits to welfare success, Washington D.C, the Brookings Institutions. 